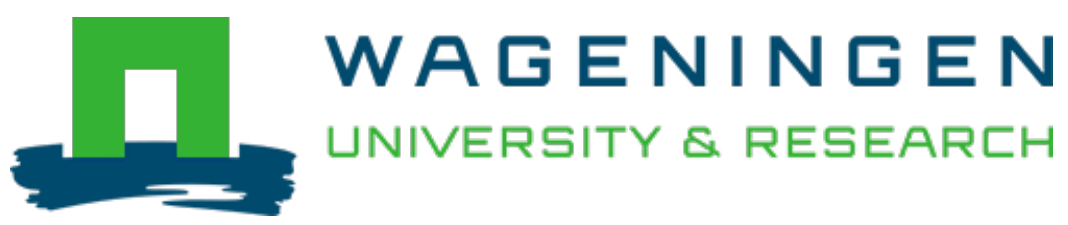

\author{
Indicators for biodiversity in agricultural landscapes: a pan-European study \\ Journal of Applied Ecology \\ Billeter, R.; Liira, J.; Bailey, D.; Bugter, R.J.F.; Arens, P.F.P. et al \\ https://doi.org/10.1111/j.1365-2664.2007.01393.x
}

This article is made publicly available in the institutional repository of Wageningen University and Research, under the terms of article $25 \mathrm{fa}$ of the Dutch Copyright Act, also known as the Amendment Taverne. This has been done with explicit consent by the author.

Article $25 \mathrm{fa}$ states that the author of a short scientific work funded either wholly or partially by Dutch public funds is entitled to make that work publicly available for no consideration following a reasonable period of time after the work was first published, provided that clear reference is made to the source of the first publication of the work.

This publication is distributed under The Association of Universities in the Netherlands (VSNU) 'Article $25 \mathrm{fa}$

implementation' project. In this project research outputs of researchers employed by Dutch Universities that comply with the legal requirements of Article $25 \mathrm{fa}$ of the Dutch Copyright Act are distributed online and free of cost or other barriers in institutional repositories. Research outputs are distributed six months after their first online publication in the original published version and with proper attribution to the source of the original publication.

You are permitted to download and use the publication for personal purposes. All rights remain with the author(s) and / or copyright owner(s) of this work. Any use of the publication or parts of it other than authorised under article $25 \mathrm{fa}$ of the Dutch Copyright act is prohibited. Wageningen University \& Research and the author(s) of this publication shall not be held responsible or liable for any damages resulting from your (re)use of this publication.

For questions regarding the public availability of this article please contact openscience.library@wur.nl 


\title{
Indicators for biodiversity in agricultural landscapes: a pan-European study
}

\author{
R. Billeter ${ }^{1 *}$, J. Liira2 ${ }^{2}$ D. Bailey ${ }^{3}$, R. Bugter ${ }^{4}$, P. Arens ${ }^{5}$, I. Augenstein ${ }^{6,12}$, S. Aviron ${ }^{3,7}$, \\ J. Baudry ${ }^{7}$, R. Bukacek ${ }^{11}$, F. Burel ${ }^{8}$, M. Cerny ${ }^{10}$, G. De Blust ${ }^{9},{\text { R. De } \text { Cock }^{9} \text {, T. Diekötter }}^{1,13}$, \\ H. Dietz ${ }^{1}$, J. Dirksen ${ }^{4}$, C. Dormann ${ }^{6}$, W. Durka ${ }^{6}$, M. Frenzel $^{6}$, R. Hamersky $^{11}$, F. Hendrickx ${ }^{9}$, \\ F. Herzog ${ }^{3}$, S. Klotz ${ }^{6}$, B. Koolstra ${ }^{4}$, A. Lausch ${ }^{6}$, D. Le Coeur ${ }^{8}$, J. P. Maelfait ${ }^{9}$, P. Opdam ${ }^{4}$, \\ M. Roubalova ${ }^{10}$, A. Schermann ${ }^{8}$, N. Schermann ${ }^{7}$, T. Schmidt $^{6}$, O. Schweiger $^{6}$, \\ M.J.M. Smulders ${ }^{5}$, M. Speelmans ${ }^{9}$, P. Simova ${ }^{11}$, J. Verboom ${ }^{4}$, W.K.R.E. van Wingerden ${ }^{4}$, \\ M. Zobel ${ }^{2}$ and P.J. Edwards ${ }^{1}$
}

${ }^{1}$ Institute of Integrative Biology, ETH Zurich, Switzerland; ${ }^{2}$ Institute of Botany and Plant Ecology, University of Tartu, Estonia; ${ }^{3}$ ART Agroscope Reckenholz Tänikon Research Station, Switzerland; ${ }^{4}$ ALTERRA Green World Research, Wageningen UR, the Netherlands; ${ }^{5}$ Plant Research International, Wageningen UR, the Netherlands; ${ }^{6}$ UFZ Helmholz Centre for Environmental Research, Germany; ${ }^{7} I N R A, S A D$ Armorique, Rennes, France; ${ }^{8} \mathrm{CNRS}$, UMR ECOBIO, Université Rennes 1, France; ${ }^{9}$ INBO, Research Institute for Nature and Forest, Belgium; ${ }^{10}$ IFER Institute of Forest Ecosystems Research Ltd, Czech Republic; ${ }^{11}$ Nature Conservation Authority, Czech Republic; ${ }^{12}$ Chair for Strategies of Landscape Management, TU Munich, Germany; and ${ }^{13}$ Department of Animal Ecology, Justus Liebig University, Germany

\section{Summary}

1. In many European agricultural landscapes, species richness is declining considerably. Studies performed at a very large spatial scale are helpful in understanding the reasons for this decline and as a basis for guiding policy. In a unique, large-scale study of 25 agricultural landscapes in seven European countries, we investigated relationships between species richness in several taxa, and the links between biodiversity and landscape structure and management.

2. We estimated the total species richness of vascular plants, birds and five arthropod groups in each $16-\mathrm{km}^{2}$ landscape, and recorded various measures of both landscape structure and intensity of agricultural land use. We studied correlations between taxonomic groups and the effects of landscape and land-use parameters on the number of species in different taxonomic groups. Our statistical approach also accounted for regional variation in species richness unrelated to landscape or land-use factors.

3. The results reveal strong geographical trends in species richness in all taxonomic groups. No single species group emerged as a good predictor of all other species groups. Species richness of all groups increased with the area of semi-natural habitats in the landscape. Species richness of birds and vascular plants was negatively associated with fertilizer use.

4. Synthesis and applications. We conclude that indicator taxa are unlikely to provide an effective means of predicting biodiversity at a large spatial scale, especially where there is large biogeographical variation in species richness. However, a small list of landscape and land-use parameters can be used in agricultural landscapes to infer large-scale patterns of species richness. Our results suggest that to halt the loss of biodiversity in these landscapes, it is important to preserve and, if possible, increase the area of semi-natural habitat.

Key-words: arthropods, birds, habitats, indicator taxa, monitoring, semi-natural plants, species richness

\footnotetext{
*Correspondence author. E-mail: regula.billeter@env.ethz.ch
} 


\section{Introduction}

Europe has a rich diversity of agricultural landscapes that differ greatly in types of land use, sizes and shapes of fields, and the abundance and pattern of semi-natural elements. Most of these landscapes, especially those with a fine-grained mosaic and low-intensity production systems, were formerly rich in biodiversity (Edwards, Kollmann \& Wood 1999). In recent decades, however, many previously common species have become scarce or have disappeared as a result of more intensive forms of agricultural production and an associated decline in semi-natural landscape elements (Krebs et al. 1999; Robinson \& Sutherland 2002). This loss of biodiversity in agricultural landscapes has been particularly marked in many member states of the European Union (EU) (e.g. farmland birds in western EU states) (Stoate et al. 2001; Donald et al. 2002), reflecting the strong environmental impact of EU agricultural policy. Although most EU countries have introduced schemes aimed at protecting biodiversity and making farming more sustainable (Kleijn et al. 2001; Stoate \& Parish 2001; Kleijn \& Sutherland 2003), many experts fear that the decline of species and habitat diversity will continue unless there are major changes in policy based on improved technology and scientific knowledge (Sala et al. 2000; Tilman et al. 2001).

Among possible factors influencing large-scale patterns of biodiversity in agricultural landscapes, habitat heterogeneity (Benton, Vickery \& Wilson 2003; Tews et al. 2004) and land-use practices - especially the application rates of fertilizers and pesticides - are thought to be particularly important. Many studies have been performed to investigate the influence of landscape structure on particular species or groups of species (e.g. Mason \& Macdonald 2000; Weibull, Bengtsson \& Nohlgren 2000; Atauri \& de Lucio 2001; Steffan-Dewenter et al. 2002; Steffan-Dewenter 2003; Purtauf, Dauber \& Wolters 2005; Vanbergen et al. 2005). Although the conclusions tend to vary according to the spatial scale and taxon investigated, all studies suggest that either heterogeneity, or connectivity, or area of semi-natural elements has a positive influence on species richness and abundance. The picture concerning land use is less clear, and the results depend very much on which land-use parameters were measured; few studies have used a broad set of variables covering several aspects of land use.

To avoid the considerable practical problems of assessing total species richness in agricultural landscapes, ecologists have explored the use of particular taxa, especially vascular plants and arthropods, as general indicators of biodiversity (Duelli 1997; Duelli \& Obrist 1998; McGeoch 1998; Pharo, Beattie \& Binns 1999). However, the growing literature on this topic reveals that, although numbers of species in different taxa are often positively correlated (Pearson \& Cassola 1992; Kati et al. 2004), these relationships are usually too weak to be useful in predicting species richness in other taxa (McGeoch 1998; Sauberer et al. 2004). Moreover, most of these studies have been performed at a relatively small spatial scale, and it is uncertain whether the findings can be applied at a larger spatial scale.
The few studies of agro-biodiversity performed at a continental scale have all had a rather narrow taxonomic focus (from our data: arthropods, Schweiger et al. 2005; Hendrickx et al. 2007; plants, J.L., unpublished data), and none has had the aim of establishing general relationships between species richness and landscape attributes that are valid for a wide range of taxa. From a European viewpoint this is unfortunate, as agricultural policies with far-reaching consequences for local biodiversity are determined centrally by the authorities of the EU. There is a danger that lessons learnt from smallscale studies, or from one or few taxonomic groups, may lead to suboptimal management practices if applied more generally. For this reason, a combination of small- and large-scale studies is needed as a basis for improving the management of agricultural landscapes (Grashof-Bokdam \& van Langevelde 2005; Tscharntke et al. 2005).

The work described here had two main objectives. First, we wanted to investigate relationships between species richness in different taxonomic species groups at a continental scale. Our motivation was to establish whether certain taxa can be used as indicators of overall species richness, thereby streamlining biodiversity assessment efforts performed at a large spatial scale. Although potential indicator taxa are often selected using correlation analysis (Lamoreux et al. 2006), this method does not provide information about the predictive power of the indicator (McGeoch 1998). We therefore adopted an alternative approach designed to identify which taxonomic groups can reliably be used to predict species richness in other groups. Our second objective was to investigate whether there are consistent relationships between species richness in selected taxa, and the structure and management of the agricultural landscape. If such large-scale relationships were demonstrated, they would provide a useful basis for biodiversity monitoring and improved landscape planning and management (Fahrig \& Jonsen 1998; Brooks \& Kennedy 2004).

The study was conducted in 25 agricultural landscapes of $16 \mathrm{~km}^{2}$ distributed across seven European countries (France, Belgium, the Netherlands, Germany, Switzerland, Czech Republic and Estonia). In a study area extending across half a continent, many factors apart from landscape and land-use variables - including climate, soil conditions and management history - also influence local species richness. Indeed, some of these factors are likely to be more important than landscape variables in determining the absolute number of species present. The analysis presented here was designed to exclude these variables so that the focus could be exclusively on how landscape structure and land-use intensity influence species richness. In each landscape we estimated the total species richness of vascular plants, birds and five arthropod groups, recorded various measures of landscape structure, and assessed the intensity of agricultural land use. In assessing landscape structure, we considered the diversity, area, and spatial arrangement of landscape elements; in assessing the intensity of agriculture, we recorded crop diversity, livestock density, and fertilizer and pesticide use. These variables cover many more aspects of the structure and management of landscapes than have been considered in most previous studies. 

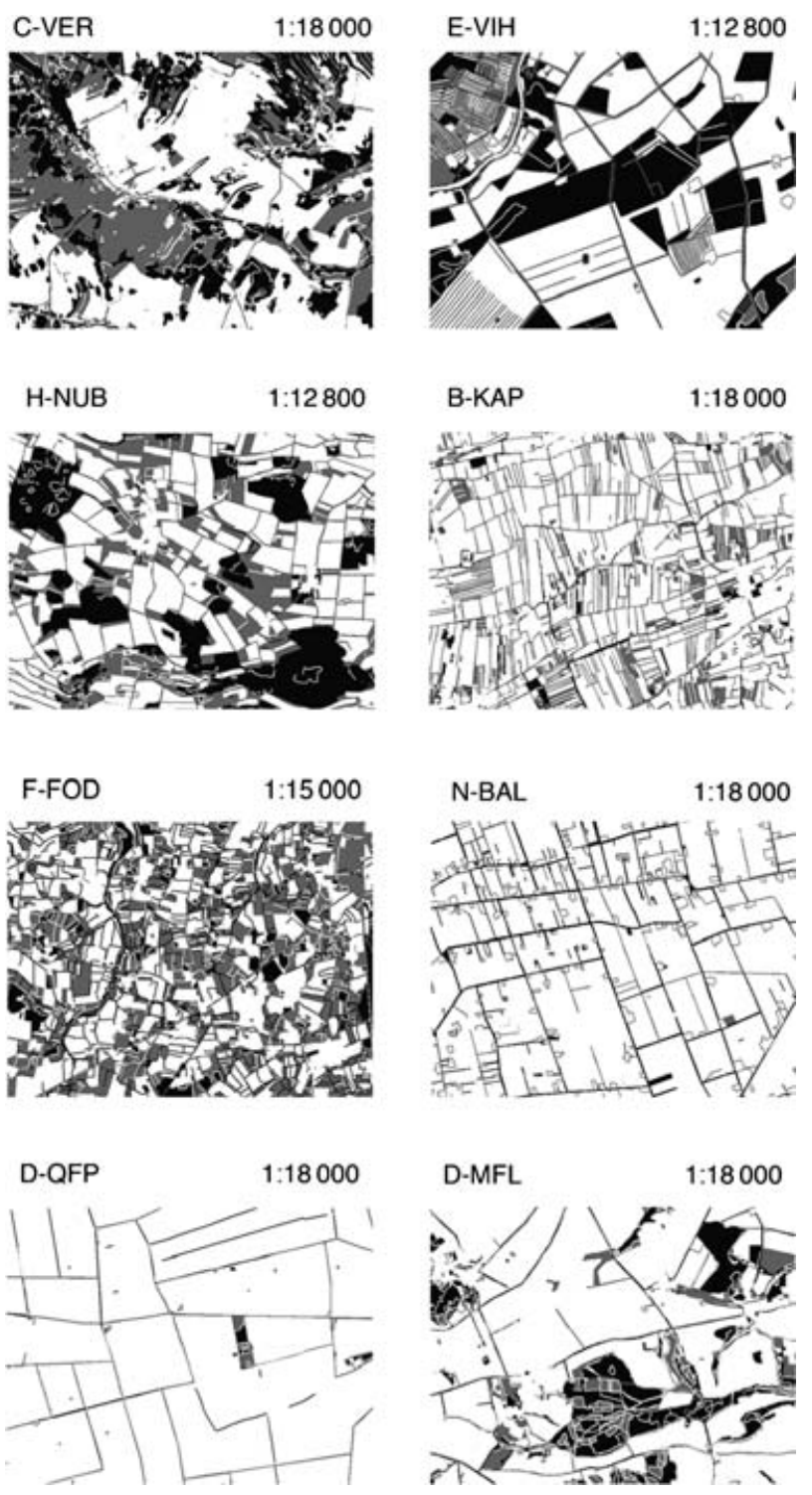

Fig. 1. Maps of eight representative study sites, which are characteristic for all sites surveyed. For site descriptions see Table 3 and Table S1 in Supplementary material. Grey = herbaceous semi-natural patches; black $=$ woody semi-natural patches; white $=$ arable land and other non-semi-natural patches.

\section{Materials and methods}

\section{STUDY SITES}

Landscapes of $16 \mathrm{~km}^{2}$ were chosen to cover broad ranges in both land-use intensity and landscape structure, with both factors varying independently as far as possible (Table S1 in Supplementary material; Fig. 1). The sites were selected to avoid strongly contrasting types of land use such as urban areas or broad river corridors. Each study site could be regarded as typical of the region, being located within a much larger agricultural area with similar landscape structure and land-use intensity. In all countries the study sites were squares of $4 \times 4 \mathrm{~km}$, except in Switzerland, where the selection criteria could only be met by choosing sites of more irregular shape.

A GIS program (ARCGIS $8 \cdot 1$; ESRI) was used to map each study site at $1-\mathrm{m}$ resolution from aerial photographs and topographical maps. The different habitat types were classified using the EUNIS Habitat Classification System (Davies \& Moss 1999). To calculate landscape and class metrics (Table 1), habitat types were aggregated into three categories: woody semi-natural habitats, herbaceous seminatural habitats, and all other habitats. Some metrics were calculated using all three categories separately, while for others the woody and herbaceous habitats were combined into a single category (GrashofBokdam \& van Langevelde 2005). Landscape and class measures were calculated at 1-m resolution using the software package FRAGSTATS (McGarigal et al. 2002). Information on land-use intensity was obtained by interviewing about 10 farmers who between them managed at least $10 \%$ of the study site. The interview contained questions about crop rotation, crop management, fertilizer and pesticide use, and livestock management (Table 1). Fertilizer input, pesticide use and livestock units were calculated per hectare of utilized agricultural area (UAA; cropland and permanent grassland).

Landscape structure varied widely in terms of the extent and types of semi-natural habitats (Fig. 1): while some landscapes had a finegrained structure with many hedgerows separating small fields (e.g. Brittany, France), others exhibited little structural diversity, being dominated by large patches of semi-natural elements (e.g. Estonia) or large fields (e.g. Querfurt, Germany). The total area of semi-natural elements in the landscapes ranged from 2 to $50 \%$, and the type and intensity of land use also varied greatly. Nitrogen input varied from $34 \mathrm{~kg} \mathrm{ha}^{-1}$ year $^{-1}$ in one Estonian site to $361 \mathrm{~kg} \mathrm{ha}^{-1}$ year $^{-1}$ in a Dutch site (Table S1). The number of crops cultivated in one year ranged from 1 to $>7$ per farm. More descriptors and the relationships among them are given by Herzog et al. (2006) and Bailey et al. (2007).

\section{BIODIVERSITY ASSESSMENT}

The taxa studied were vascular plants, birds, bees (Apoidea), true bugs (Heteroptera), carabid beetles (Carabidae), hoverflies (Syrphidae) and spiders (Araneae). Plants and birds were surveyed in all sites, and arthropods in 24 sites.

The plots for recording plants were located using a stratified random sampling scheme. The plots for recording the herbaceous layer were $2 \times 2 \mathrm{~m}$, and those for the shrub and tree layer, if present, $20 \times 20 \mathrm{~m}$. The sampling protocol required the plant plots to be distributed among agricultural, semi-natural and linear elements in the ratio $1: 4: 5$ - to avoid over-representation of particular habitat types - and with a total sample of 200-250 plots per site. In practice, the sample size ranged between 86 and 323 per study site, but the ratios among the elements remained constant. To facilitate comparisons, the mean numbers of plant species in 86 plots, rarefied from the original data, are presented as well as the original data in Table 2. As the Spearman correlation coefficient between observed herb-layer richness and rarefied richness was very high (herbs $r=0.96 ; P<0.001$; woody plants $r=0.92, P<0 \cdot 001)$, the observed data set was used for statistical analyses; the variation in sampling intensity of vegetation was taken into account with a continuous factor 'log-transformed number of samples', utilizing the species-area accumulation curve (Arrhenius 1921).

For bird sampling, the study site was divided into $1-\mathrm{km}^{2}$ grid cells. Bird diversity was measured by making point-counts in five central grid cells selected in a checkerboard pattern. Within each cell, four observation points were selected, and at each point sightings and hearings of birds were counted for $5 \mathrm{~min}$ from $30 \mathrm{~min}$ before until 2 $\mathrm{h}$ after sunrise. This procedure was repeated in April, May and June.

Arthropods were sampled using 16 pairs of pitfall traps and 16 pairs of combined flight-intercept traps (combined window-glass and yellow-pan trap) located using a stratified random distribution, 
Table 1. Explanatory variables used in the statistical analysis

\begin{tabular}{|c|c|c|}
\hline Variable name & Explanation & Range (min-max) \\
\hline Country & Country & \\
\hline Taxonomic group & Taxonomic or morphological group of species & \\
\hline Vegetation period & $\begin{array}{l}\text { Length of vegetation period (average number of days 1982-2001 with daily } \\
\text { temperature }>5^{\circ} \mathrm{C} \text { ) }\end{array}$ & 235-291 days \\
\hline Number of plots & Number of vegetation sample plots in study site & $84-323$ \\
\hline \multicolumn{3}{|l|}{ Land-use intensity parameters } \\
\hline Crop diversity & Average number of crops cultivated on a farm & $1 \cdot 2-7 \cdot 7$ \\
\hline Fertilizer input ha ${ }^{-1}$ UAA & Average nitrogen input scaled to the UAA & $34-361 \mathrm{~kg} \mathrm{ha}^{-1}$ year $^{-1}$ \\
\hline Intensely fertilized land & $\begin{array}{l}\text { Share of intensively fertilized arable area }\left(>150 \mathrm{~kg} \mathrm{~N} \mathrm{ha}^{-1} \text { year }^{-1}\right) \text { scaled to the } \\
\text { UAA }\end{array}$ & $0-98 \cdot 6 \%$ \\
\hline Livestock units & Average amount of livestock units per farm in study site, scaled to the UAA & $0-4 \cdot 7 \mathrm{lu}$ \\
\hline Pesticide application & $\begin{array}{l}\text { Average number of pesticide applications per field in study site, scaled to the } \\
\text { UAA }\end{array}$ & $0-5 \cdot 8$ \\
\hline \multicolumn{3}{|l|}{ Landscape parameters } \\
\hline Share of semi-natural elements & Area $\left(\mathrm{m}^{2}\right)$ of semi-natural habitats in study site & $2 \cdot 69-52 \cdot 96 \%$ \\
\hline Habitat diversity & Number of semi-natural habitat types in study site & $12-23$ \\
\hline Patch. $\mathrm{No}_{\mathrm{WH}}$ & Number of patches of woody and herbaceous semi-natural habitats & $126-2027$ \\
\hline Patch.Area $\mathrm{GV}$ & Average size of a semi-natural patch & $1965-29136 \mathrm{~m}^{2}$ \\
\hline Patch.Density $_{\mathrm{GV}}$ & $\begin{array}{l}\text { Number of patches of woody and herbaceous semi-natural habitats per } \\
100 \text { ha }\end{array}$ & $7 \cdot 88-126 \cdot 69$ \\
\hline Edge.Density $_{\mathrm{GV}}$ & Average edge density of semi-natural habitats in study site & $97 \cdot 65-579 \cdot 63 \mathrm{~m} \mathrm{ha}^{-1}$ \\
\hline $\mathrm{ENN}_{\mathrm{GV}}$ & $\begin{array}{l}\text { Average euclidean-nearest-neighbour distance between semi-natural } \\
\text { landscape elements in study site }\end{array}$ & $9 \cdot 51-53 \cdot 02 \mathrm{~m}$ \\
\hline Contag $_{\mathrm{GV}}$ & Contagion index of woody and herbaceous semi-natural landscape elements & $37 \cdot 61-76 \cdot 73 \%$ \\
\hline $\operatorname{Prox}_{\mathrm{GV}}$ & $\begin{array}{l}\text { Proximity of woody and herbaceous semi-natural elements within a 5000-m } \\
\text { radius }\end{array}$ & $295 \cdot 07-60321 \cdot 11$ \\
\hline
\end{tabular}

$\mathrm{UAA}=$ utilized agicultural area.

Table 2. Total species numbers of vascular plants (separated into herbaceous and woody plants) and six animal taxa recorded in 25 landscape study sites. Observed and mean species number of herbaceous and woody plants found in 86 plots based upon a rarefaction of the original data are shown

\begin{tabular}{|c|c|c|c|c|c|c|c|c|c|c|c|}
\hline Country & $\begin{array}{l}\text { Site } \\
\text { code }\end{array}$ & $\begin{array}{l}\text { Herbs } \\
\text { (observed) }\end{array}$ & $\begin{array}{l}\text { Herbs } \\
\text { (86 plots) }\end{array}$ & $\begin{array}{l}\text { Woody } \\
\text { (observed) }\end{array}$ & $\begin{array}{l}\text { Woody } \\
\text { (86 plots) }\end{array}$ & Birds & Spiders & Carabids & $\begin{array}{l}\text { True } \\
\text { bugs }\end{array}$ & Hoverflies & Bees \\
\hline \multirow{4}{*}{ Belgium } & B-BRE & 240 & $156 \cdot 8$ & 36 & $28 \cdot 0$ & 63 & 107 & 77 & 36 & 24 & 38 \\
\hline & B-HOE & 287 & $187 \cdot 8$ & 60 & $41 \cdot 7$ & 52 & 74 & 69 & 32 & 22 & 40 \\
\hline & B-KAP & 192 & $131 \cdot 2$ & 63 & $35 \cdot 7$ & 59 & 73 & 67 & 24 & 27 & 15 \\
\hline & B-VOE & 284 & $189 \cdot 6$ & 56 & $36 \cdot 6$ & 58 & 67 & 59 & 36 & 21 & 36 \\
\hline \multirow[t]{3}{*}{ Czech Rep. } & C-BRO & 328 & $204 \cdot 4$ & 48 & $32 \cdot 0$ & 50 & 68 & 47 & 27 & 13 & 63 \\
\hline & C-SVE & 274 & $192 \cdot 7$ & 41 & $26 \cdot 9$ & 56 & - & - & - & - & - \\
\hline & C-VER & 339 & $230 \cdot 4$ & 57 & $33 \cdot 4$ & 47 & 78 & 60 & 88 & 40 & 50 \\
\hline \multirow{4}{*}{ Estonia } & E-ARE & 293 & 211 & 30 & $22 \cdot 7$ & 52 & 101 & 69 & 48 & 28 & 33 \\
\hline & E-VIH & 280 & $204 \cdot 4$ & 27 & $22 \cdot 1$ & 53 & 118 & 82 & 73 & 35 & 45 \\
\hline & E-Vii & 270 & $189 \cdot 6$ & 38 & $27 \cdot 0$ & 38 & 84 & 75 & 52 & 32 & 40 \\
\hline & E-VMA & 255 & $181 \cdot 2$ & 37 & $26 \cdot 4$ & 37 & 104 & 80 & 75 & 33 & 42 \\
\hline \multirow[t]{3}{*}{ France } & F-AL & 278 & $204 \cdot 1$ & 42 & $29 \cdot 1$ & 39 & 79 & 67 & 58 & 23 & 38 \\
\hline & F-FOD & 301 & $183 \cdot 4$ & 43 & $27 \cdot 3$ & 46 & 91 & 79 & 60 & 20 & 44 \\
\hline & F-FOO & 274 & 190 & 49 & 31.9 & 42 & 92 & 75 & 56 & 17 & 41 \\
\hline \multirow[t]{4}{*}{ Germany } & D-FRI & 266 & 187 & 27 & $18 \cdot 5$ & 63 & 90 & 73 & 69 & 19 & 125 \\
\hline & D-MFL & 251 & $163 \cdot 2$ & 32 & $24 \cdot 5$ & 67 & 105 & 83 & 89 & 49 & 98 \\
\hline & D-QFP & 152 & 121 & 24 & $16 \cdot 8$ & 50 & 81 & 72 & 68 & 37 & 96 \\
\hline & D-WAN & 237 & $170 \cdot 8$ & 40 & $25 \cdot 1$ & 58 & 89 & 78 & 86 & 26 & 99 \\
\hline \multirow{4}{*}{ Netherlands } & N-BAL & 161 & $159 \cdot 7$ & 18 & $17 \cdot 7$ & 49 & 74 & 63 & 27 & 28 & 16 \\
\hline & N-BEN & 223 & $183 \cdot 8$ & 54 & $45 \cdot 6$ & 59 & 77 & 54 & 43 & 21 & 32 \\
\hline & N-SCH & 143 & $127 \cdot 8$ & 33 & $29 \cdot 5$ & 56 & 74 & 69 & 32 & 25 & 23 \\
\hline & N-WEE & 185 & $157 \cdot 5$ & 45 & $38 \cdot 5$ & 62 & 73 & 71 & 32 & 19 & 22 \\
\hline \multirow[t]{3}{*}{ Switzerland } & H-KLG & 274 & $196 \cdot 9$ & 46 & $29 \cdot 7$ & 43 & 62 & 52 & 104 & 26 & 59 \\
\hline & H-NUB & 314 & $208 \cdot 3$ & 44 & $32 \cdot 1$ & 53 & 76 & 61 & 88 & 55 & 64 \\
\hline & H-REE & 340 & $212 \cdot 3$ & 42 & $31 \cdot 1$ & 62 & 91 & 66 & 80 & 54 & 62 \\
\hline
\end{tabular}


with two sets of traps in each 1-km² grid cell. At each location, two sets of one pitfall and one flight trap each were placed $25-50 \mathrm{~m}$ apart at the border between a semi-natural habitat and agricultural land. For a detailed description of the sampling procedure see Schweiger et al. (2005). Sampling was carried out according to the procedures of Duelli (1997). Species numbers for all species groups in every landscape are presented in Table 2.

\section{STATISTICAL ANALYSIS}

In a first step, we investigated the predictive power of the different species groups. We calculated predictive correlations between species groups using general linear modelling with stepwise selection procedure for all groups of taxa and the factor variable 'country'. Country was used as compound variable to account for biogeographical variation within Europe. If one group is clearly superior as a predictor of species richness, then the final model may include just one species group, or it may include several groups and/or the biogeographical effects if there is no single best indicator group.

Second, we analysed the effect of landscape and land-use parameters on the number of species in different taxonomic or morphological groups. We created general linear mixed models using the statistical package sAS ver. 8·2 (procedure 'mixed'; Littell et al. 1996). Separate models were built for plant diversity (two groups: woody and herbaceous), bird diversity (one group) and arthropod diversity (five groups: bees, carabids, true bugs, hoverflies and spiders). Taxonomic groups were analysed in separate models according to the sampling methods. Where more than one species group was involved (plants and arthropods), the species group was treated as a factor with discrete levels. Any regional variation in species richness unrelated to landscape or land-use factors was accounted for by the continuous variable 'length of vegetation period' and the random factor country within the 'country $\times$ species group' term. The interaction term 'country $\times$ species group' was treated as a random factor as each species group has its own species pool within a country. The 'length of vegetation period' was excluded during the stepwise model building as a non-significant predictor, with only the 'country effect' being used in the final models to account for geographical variations. Because of the random effects in the model, we used the Satterthwaite approximation for the denominator degrees of freedom. We included a repeated statement with an unstructured covariance matrix in the plant and arthropod models; this took account of any autocorrelation caused by sampling both plant species groups or all five arthropod species groups in the same locations within a study site. Landscape and land-use parameters were included in the models as continuous predictors (Table 1). In the plant model, we included the log-transformed number of sample plots to correct for sampling intensity.

The statistically significant main effects of the environmental variables describe the general pooled trends of all species groups in a model. Significant interaction terms between the species groups and the continuous variables indicate differences in correlation among the environmental parameters and the number of species within a group.

The procedure for model building was stepwise backward. Variables for which neither the main effect nor the interaction term with the species group was significant were excluded step by step, and the procedure stopped when all environmental variables showed either a significant main effect or interaction term $(P<0 \cdot 05)$. To avoid over-parameterization (Shao 1997), Akaike's information criterion (Akaike 1973) was used to test for the optimal set of variables in a model according to its predictive power. The results of the final models are presented with slope parameter estimates for the main effects (interaction term not significant) or separate slope estimates for each species group (interaction term significant, see Table 4). Slope parameters were tested for their difference from zero ( $t$-test) within the mixed model. It is not possible to calculate multiple determination coefficient $\left(R^{2}\right)$ values directly for mixed models with random factors and repeated settings, but the approximate estimate of $R^{2}$ was obtained from the likelihood ratio test statistic of a model (Magee 1990).

\section{Results}

\section{PREDICTIVE CORRELATIONS AMONG SPECIES GROUPS}

Several significant predictive relationships between numbers of species in different taxa were obtained (Table 3), but no taxon proved to be a good predictor for all others. The optimal predictive model for most groups involved one or two indicator groups in combination with the country effect. The descriptive power of the indicator model varied from $34 \%$ for woody plants to $94 \%$ for bees. Among the individual groups, bees proved to be a good indicator taxon for species richness of herbs, spiders for birds, and carabids for hoverflies. Paired indicator groups were found for three taxonomic groups bees were best predicted by herbs and hoverflies, carabids by herbs and spiders, and spiders by carabids and birds. Neither species richness of woody plants nor bugs could be predicted by any other group. For most species groups there was a significant country effect, indicating strong biogeographical variation in species numbers. All indicative correlations were positive except for those of carabids against plants, and bees against hoverflies (Table 3).

\section{CORRELATIONS WITH LANDSCAPE AND LAND-USE INDICATORS}

For all taxonomic groups, variables describing landscape structure and land-use intensity accounted for a significant part of the variation in species richness. The same analyses were also performed using Simpson's diversity index, but the results are not presented here because the relationships were very similar to those obtained using species richness.

The total number of vascular plant species increased with the area of semi-natural habitat in the study site, and decreased with the percentage of heavily fertilized agricultural land (after considering the variation in sampling intensity; Table 4). Significant interaction terms revealed that these relationships were due to variation in the numbers of herbaceous species and that numbers of woody species were unaffected by these factors (Table 4, Fig. 2).

The trends for birds were similar to those for plants, with the number of species being positively related to the area of semi-natural habitat in the study site and negatively related to fertilizer input (annual $\mathrm{N}$ input in $\mathrm{kg} \mathrm{ha}^{-1}$ utilized agricultural area, Table 4, Fig. 3).

The combined species richness of the five arthropod taxa also increased with the area of semi-natural habitat in the study site (Table 4, Fig. 4). However, unlike for birds and plants, 
Table 3. Results of the GLM analysis for predictive correlations. This is a critical list of indicator groups for predicting species richness of each species group, considering factor effect by country. Significant effects are presented with slope estimate and significance class. Estimates for intercept and/or country are not presented. MPE, multiple parameter estimates

\begin{tabular}{|c|c|c|c|c|c|c|c|c|}
\hline \multirow[b]{2}{*}{ Indicator group } & \multicolumn{8}{|c|}{ Species richness of group to be predicted } \\
\hline & Herbs & Woody & Birds & Bees & True bugs & Carabids & Hoverflies & Spiders \\
\hline Herbs & & & & $0 \cdot 204^{*}$ & & $-0.098^{*}$ & & \\
\hline \multicolumn{9}{|l|}{ Woody } \\
\hline Birds & & & & & & & & $0 \cdot 873 * *$ \\
\hline Bees & $1 \cdot 356^{*}$ & & & & & & & \\
\hline \multicolumn{9}{|l|}{ True bugs } \\
\hline Carabids & & & & & & & $0 \cdot 722^{*}$ & $0.912 * *$ \\
\hline Hoverflies & & & & $-0 \cdot 392 *$ & & & & \\
\hline Spiders & & & $0 \cdot 366^{* *}$ & & & $0 \cdot 551^{* * *}$ & & \\
\hline Country & $\mathrm{MPE}^{* *}$ & MPE* & $\mathrm{MPE}^{* * *}$ & $\mathrm{MPE}^{* * *}$ & $\mathrm{MPE}^{* * *}$ & & MPE* & MPE* \\
\hline $\operatorname{adj} R^{2}$ & $0 \cdot 586$ & $0 \cdot 338$ & $0 \cdot 641$ & $0 \cdot 941$ & $0 \cdot 660$ & $0 \cdot 681$ & $0 \cdot 440$ & 0.739 \\
\hline Model $P$ & $0 \cdot 002$ & 0.036 & $0 \cdot 001$ & $0 \cdot 001$ & 0.001 & 0.001 & $0 \cdot 016$ & 0.001 \\
\hline
\end{tabular}

Presented is a critical list of indicator groups for predicting species richness of each species group, considering factor effect by country. Significant effects are presented with slope estimate and significance class. Estimates for intercept and/or country are not presented. MPE, multiple parameter estimates.

* $P \leq 0 \cdot 05 ; * * P \leq 0 \cdot 01 ; * * P \leq 0 \cdot 001$.

Table 4. Results of GLMM analysis of the relationships between biodiversity and landscape, and land-use variables. Results of individual groups are given with homogeneity group classes of the slope values indicated by superscript labels (for significant interactions terms only). Degrees of freedom were rounded to avoid decimals.

\begin{tabular}{|c|c|c|c|c|c|c|c|}
\hline Effect & d.f. & $F$ & $P$ & Group & Slope & SE & $P$ \\
\hline \multicolumn{8}{|l|}{ Plants $\left(R^{2}=81 \cdot 2 \%\right)$} \\
\hline Growth form & 1,23 & $51 \cdot 97$ & $<0 \cdot 001$ & & & & \\
\hline Log (number of plots) & 1,22 & $12 \cdot 80$ & $<0.002$ & & & & \\
\hline Share of semi-natural elements ( $\%$ area) & 1,20 & $6 \cdot 02$ & $<0.024$ & & & & \\
\hline \multirow[t]{2}{*}{ Growth form $\times$ share of semi-natural elements } & 1,22 & $7 \cdot 38$ & $<0 \cdot 013$ & Herbs & $1 \cdot 718$ & $0 \cdot 636$ & $<0 \cdot 014$ \\
\hline & & & & Woody & $-0 \cdot 052$ & $0 \cdot 195$ & $0 \cdot 794$ \\
\hline Intensely fertilized land ( $\%$ area) & 1,24 & $5 \cdot 24$ & $<0 \cdot 032$ & & & & \\
\hline \multirow[t]{2}{*}{ Growth form $\times$ intensely fertilized land } & 1,24 & $8 \cdot 38$ & $<0.009$ & Herbs & $-0 \cdot 717$ & $0 \cdot 262$ & $<0 \cdot 012$ \\
\hline & & & & Woody & $0 \cdot 065$ & $0 \cdot 093$ & $0 \cdot 486$ \\
\hline \multicolumn{8}{|l|}{$\operatorname{Birds}\left(R^{2}=25 \cdot 6 \%\right)$} \\
\hline Share of semi-natural elements ( $\%$ area) & 1,17 & $7 \cdot 36$ & $<0 \cdot 016$ & & $0 \cdot 282$ & $0 \cdot 165$ & \\
\hline Fertilizer input $\left(\mathrm{kg} \mathrm{N} \mathrm{ha}^{-1}\right.$ year $\left.^{-1}\right)$ & 1,18 & $4 \cdot 93$ & $<0 \cdot 040$ & & $-0 \cdot 037$ & $0 \cdot 104$ & \\
\hline \multicolumn{8}{|l|}{ Arthropods $\left(R^{2}=37 \cdot 1 \%\right)$} \\
\hline Taxonomic group & 4,22 & $2 \cdot 71$ & $0 \cdot 051$ & & & & \\
\hline Share of semi-natural elements ( $\%$ area) & 1,25 & $13 \cdot 77$ & $<0 \cdot 002$ & & $0 \cdot 312$ & $0 \cdot 061$ & \\
\hline Taxonomic group $\times$ share of semi-natural elements & 4,21 & $1 \cdot 09$ & $0 \cdot 361$ & & & & \\
\hline Crop diversity & 1,26 & $7 \cdot 40$ & $<0 \cdot 015$ & & $2 \cdot 284$ & $0 \cdot 426$ & \\
\hline Taxonomic group $\times$ crop diversity & 4,21 & $1 \cdot 21$ & 0.437 & & & & \\
\hline Habitat diversity & 1,24 & $0 \cdot 01$ & $0 \cdot 935$ & & & & \\
\hline \multirow[t]{5}{*}{ Taxonomic group $\times$ habitat diversity } & 4,20 & $3 \cdot 21$ & $<0.048$ & Bees & $1 \cdot 621^{\mathrm{a}}$ & $0 \cdot 574$ & $<0 \cdot 011$ \\
\hline & & & & Bugs & $-0 \cdot 616^{\mathrm{b}}$ & $1 \cdot 167$ & $0 \cdot 587$ \\
\hline & & & & Carabids & $-0 \cdot 405^{\mathrm{b}}$ & $0 \cdot 527$ & $0 \cdot 450$ \\
\hline & & & & Hoverflies & $-0 \cdot 333^{\mathrm{ab}}$ & $0 \cdot 775$ & 0.672 \\
\hline & & & & Spiders & $0 \cdot 786^{\mathrm{ab}}$ & $0 \cdot 967$ & $0 \cdot 425$ \\
\hline
\end{tabular}

crop diversity also had a positive effect on species richness (Table 4, Fig. 4). Species numbers of bees but not of other arthropods were positively related to the diversity of seminatural habitat types (Table 4, Fig. 4).

No other factors entered into the models explained a significant part of the variation in the species richness of any taxonomic group.

\section{Discussion}

\section{PREDICTIVE CORRELATIONS AMONG SPECIES GROUPS}

Our results suggest that no single species group can be used as a surrogate measure of species richness for all others. It could 


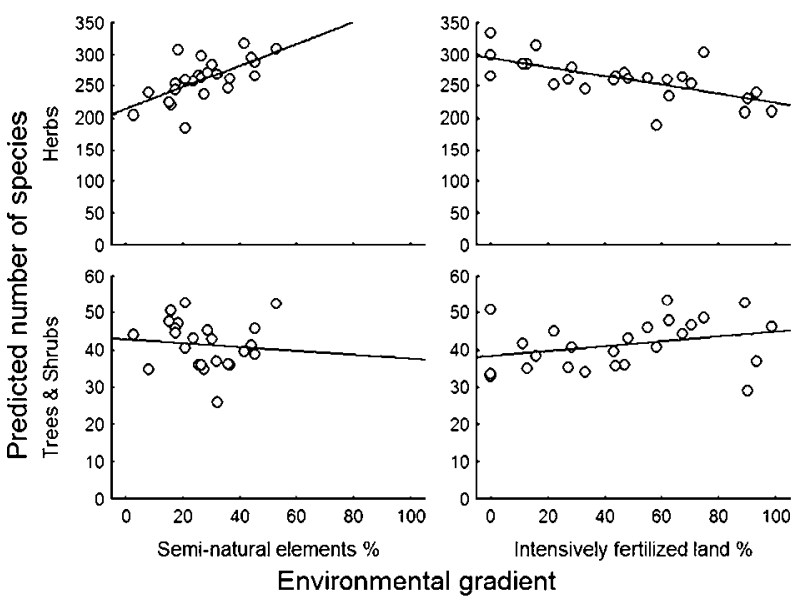

Fig. 2. Relationships between number of plant species in the study sites and landscape structure (percentage of semi-natural habitats, $P<0 \cdot 014$, for herbs only) and land-use intensity (percentage of intensively fertilized agricultural land, $P<0 \cdot 012$, for herbs only). Dots represent variation around the model predicted factor effects (solid line).

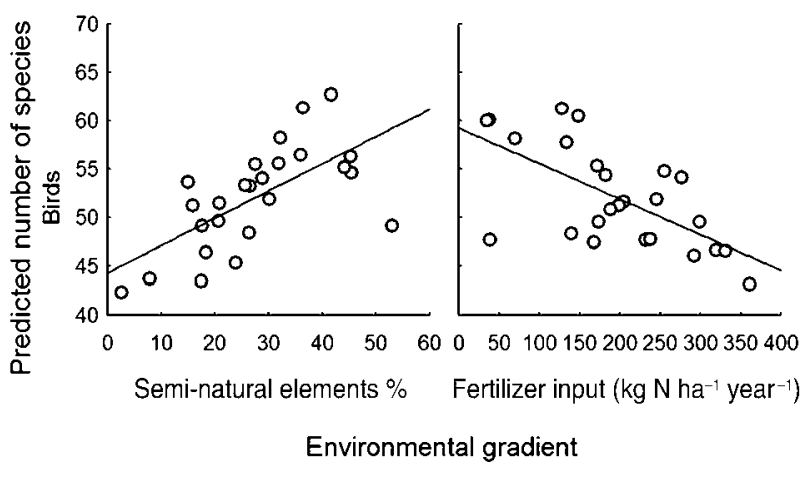

Fig. 3. Relationships between number of bird species in the study sites and landscape structure (percentage of semi-natural habitats, $P<0 \cdot 016$ ) and land-use intensity (total nitrogen applied per hectare of agricultural land, $P<0 \cdot 040$ ). Dots represent variation around the model predicted factor effects (solid line).
Fig. 4. Relationships between species number of the five arthropod species groups in the study sites, landscape structure and land use (percentage of semi-natural habitats, $P<0 \cdot 002$; habitat diversity, $P<0 \cdot 011$, for bees only; crop diversity, $P<0 \cdot 015$ ). Dots represent variation around the model predicted factor effects (solid line).
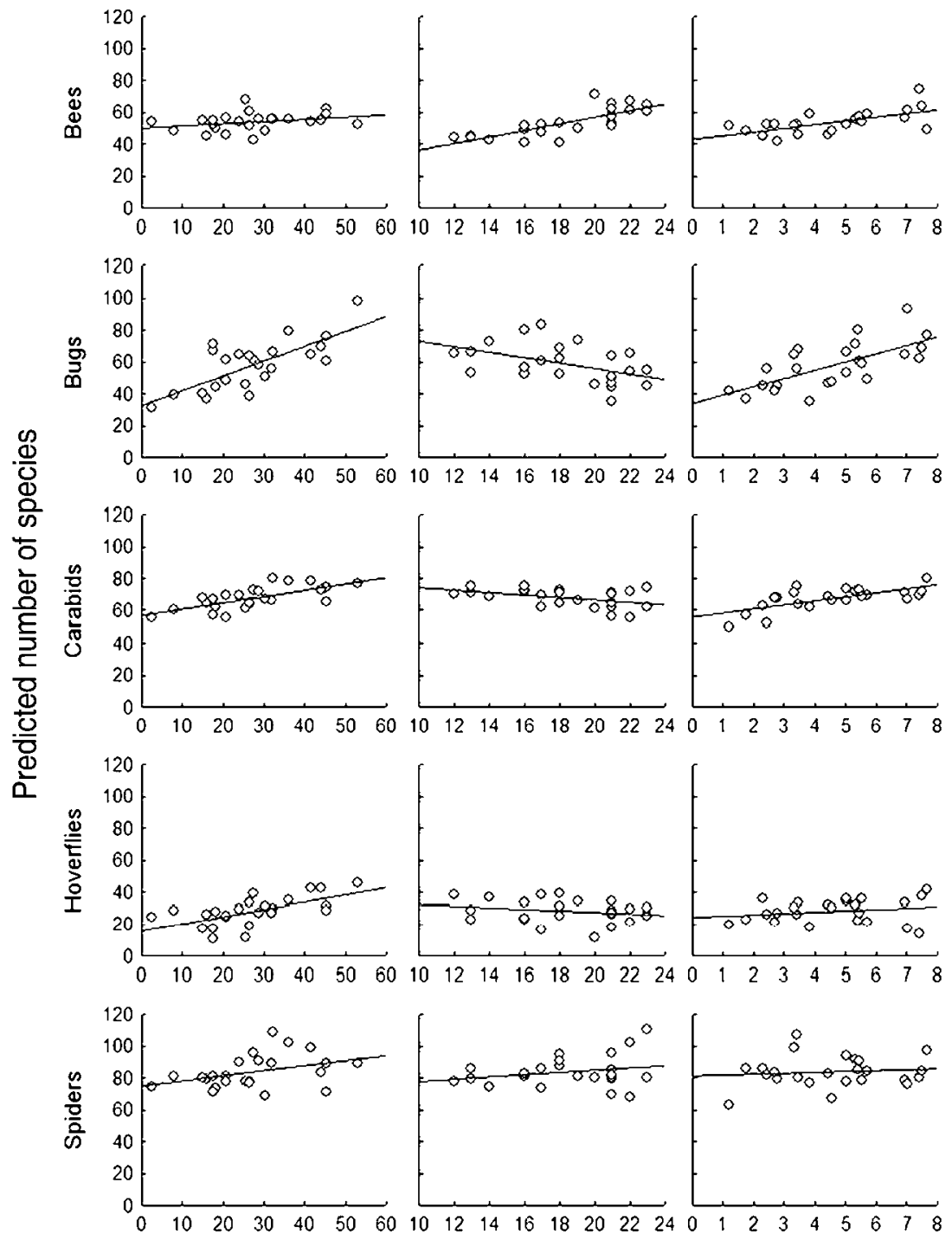

Semi-natural elements \%

Habitat diversity

Crop diversity

Environmental gradient 
potentially be suggested that the correlation between spiders and carabids may be spurious due to the fact that trapping efficiency of traps can be related to local conditions and installation (Topping \& Sunderland 1992). However, the same was not observed for species studied with flight traps. It is likely that simple ecological causes, such as similar habitat preferences or similar prey selection, may also be good explanations for the strong correlation observed between these two groups.

The strong influence of the variable country - which can be interpreted as representing geographical variation in species richness - further complicates the use of individual taxa as indicators of species richness at a continental scale. This finding is consistent with some published studies (van Jaarsveld et al. 1998; Vessby et al. 2002) but not with others (Pearson \& Cassola 1992; Duelli 1997; Kati et al. 2004). We suggest two ways to explain this inconsistency. First, few if any other studies have considered such a wide range of species groups, and the positive relationships that have been established among some species groups may not be more generally applicable. Second, many conflicting results may stem from differences in the spatial scale at which the various studies were conducted, underlining the dangers of upscaling conclusions from small-scale studies to regions or continents.

\section{CORRELATION WITH LANDSCAPE AND LAND-USE INDICATORS}

The landscapes chosen for our study covered wide ranges of both landscape structure and land-use intensity (Table S1), with the two sets of variables varying more-or-less independently. The landscapes were very different in structure, not only in the total area of semi-natural habitat, but also in the spatial arrangement of the various elements (Fig. 1) and in the land-use intensity. However, despite the structural diversity, two general landscape parameters were distinguished that contributed significantly to explaining species richness across the very different taxonomic groups. By far the most important of these was the share of semi-natural habitat in the study sites, which was positively correlated with species richness for vascular plants, birds and arthropods. The consistent importance of this species-area relationship suggests that, in most agricultural landscapes, the largest contribution to total biodiversity comes from the natural and semi-natural habitats and is directly influenced by their area. Many other studies have shown similarly positive relations between numbers of species and area of semi-natural habitat (Bruun 2000; Steffan-Dewenter et al. 2002; Kremen et al. 2004). Not only are many species confined to these habitats, but some species closely associated with agro-ecosystems may require the presence of seminatural habitats. For example, it has been shown that more than $63 \%$ of all animal species living in agricultural areas depend on semi-natural habitats for their survival (Duelli \& Obrist 2003), demonstrating the crucial importance of these habitats. The only other landscape parameter that contributed significantly to species richness was habitat diversity, which was positively associated with the number of bee species. This is not surprising, as many bee species require several different and sometimes also very specific habitat types to persist in a landscape (Westrich 1996).

Of the five variables used to characterize agricultural land-use, none was consistently important in explaining species richness, but three were significant for particular taxonomic groups. The number of vascular plant species was negatively related to the percentage of intensively fertilized land. This can be readily understood, as fertilizer application is known to reduce plant species richness in both arable fields and agricultural grasslands (Ditommaso \& Aarssen 1989; Gough et al. 2000; Myklestad \& Saetersdal 2005); and nonagricultural habitats can also be affected as a result of the lateral movement of fertilizer in the air and groundwater (Kleijn \& Snoeijing 1997; de Snoo \& van der Poll 1999; Marshall \& Moonen 2002). The numbers of birds were also negatively correlated with the mean input of $\mathrm{N}$. In this case, the effect is likely to be indirect: high levels of agrochemicals have been associated with both a lower availability of weed seeds - which are an important component of the diet of many farmland birds (Watkinson et al. 2000; Marshall et al. 2003) and with a lower biomass of many insect species (Di Giulio \& Edwards 2003). The third significant land-use variable was crop diversity, which was positively associated with the species richness of arthropods, and particularly of bees, carabids and bugs (interaction not significant, but see Fig. 4). This is an interesting result because it shows that species richness in an agricultural landscape is not solely dependent on the semi-natural habitats, but is also affected by the diversity of forms of agriculture (Tscharntke et al. 2005). The case of bees is particularly significant because this group -including many ecologically demanding species requiring specific habitats for foraging and nesting (Westrich 1996) - is economically highly important for agriculture. In summary, our data show species richness at the landscape scale to be predicted by a very few variables representing land-use intensity and the spatial structure of both agricultural and semi-natural areas.

In view of these results, it is appropriate to ask why other landscape parameters had no influence on species richness; the connectivity of habitats, for example, is known to affect the ability of some species to persist in fragmented landscapes (Tscharntke et al. 2002; Steffan-Dewenter 2003), yet there were no significant relationships with relevant parameters such as edge density or average Euclidean nearest-neighbour distance between semi-natural elements. One possible reason is that many of the landscape parameters were correlated with each other, and the method of variable selection in the multiple regressions may have excluded some functionally important variables in favour of others. A more basic reason is probably that this study provides the 'large picture', with the results differing from those of smaller-scale studies in important ways. First, the relationships demonstrated here are based on numbers of species within large taxonomic groups, and do not necessarily reflect the needs of individual species. Appropriate measures of connectivity vary greatly according to species, and such detailed information must come from smaller-scale studies focused on individual species 
groups (Mason \& Macdonald 2000; Steffan-Dewenter et al. 2002; Steffan-Dewenter 2003; Vanbergen et al. 2005). Second, there may be contradictory trends among different taxa within major species groups that are not evident from our broad analysis. Further analyses of our data for individual taxonomic groups at a more detailed scale may yield deeper insights into the relationships between biodiversity and agriculture across temperate Europe. For example Schweiger et al. (2005) analysed community composition of the arthropod groups in detail, and found responses to landscape structure and land use not only at the level of species group, but also in relation to trophic status and body size. Hendrickx et al. (2007) focused on the roles of $\alpha$-, $\beta$ - and $\gamma$-diversity in arthropod richness, and could show that the decrease in total species richness could be attributed primarily to a decrease in species diversity between local communities ( $\beta$-diversity). They concluded that 'the effects of agricultural change operate at a landscape level and that examining species diversity at a local level fails to explain the total species richness of an agricultural landscape.' A detailed analysis of the composition and richness of plant functional groups (J.L., unpublished data) showed that generalizations obtained from mobile taxa such as insects are not applicable to plants, for which habitat availability and quality are the most important determinants at the landscape scale.

\section{IMPLICATIONS FOR MANAGEMENT}

Policy-makers increasingly accept that preserving biodiversity is important for the functioning and stability of ecosystems and for the provision of ecosystem services, as well as being justifiable on moral, ethical and aesthetic grounds (Loreau et al. 2001; Kremen 2005). For this reason, a major objective of most environmental policies related to the agricultural landscape is to maintain or enhance biodiversity. For practical reasons, most monitoring systems are based on small-scale surveys, but the results of such studies do not necessarily provide useful information about trends at regional, national or even continental scales (Kleijn et al. 2001; Robinson \& Sutherland 2002). To improve environmental management and policy, however, reliable yet easy-to-use indicators are needed for assessing biodiversity at a large spatial scale.

Our study - one of the first to investigate biodiversity relationships at a pan-European scale - shows that at a large scale it may not be possible to use one species group as an indicator for all others. However, the results do suggest that a small list of landscape and land-use parameters can be used to assess environmental conditions for biodiversity at a large spatial scale in agricultural landscapes (e.g. for the EU Sixth Environment Action Programme, Environment 2010; http:// ec.europa.eu/agriculture/capreform/index.htm). In combination with smaller-scale studies of individual species, large-scale studies such as the one presented here will improve our understanding of the mechanisms contributing to the species richness of agricultural landscapes, and help us find ways of preserving this diversity. But without waiting for such studies, a simple, first step to meeting the 2010 target of the
EU Action Programme would be to increase the amount of semi-natural habitats per landscape unit. The possible tradeoff between conservation benefits and economic losses may cause some discussion, but the gains would seem to be larger than any losses in total production (Green et al. 2005).

\section{Acknowledgements}

We thank the numerous helpers, the farmers, the specialists for arthropod determinations, C. Ter Braak for statistical advice, S. Stöckli for data on vegetation periods, and three anonymous reviewers for valuable comments. The GREENVEINS project was funded by the Energy, Environment and Sustainable Development Programme (FP5) of the European Commission (contract number EVK2-CT-2000-00082). The Swiss partners were funded by the Swiss State Secretary for Education and Research. The Dutch partners received funding from the Netherlands' Ministry of Agriculture, Nature and Food Safety.

\section{References}

Akaike, H. (1973) Information theory and an extension of the maximum likelihood principle. Second International Symposium on Information Theory (eds B.N. Petrov \& F. Csaki), pp. 267-281. Akademiai Kiado, Budapest.

Arrhenius, O. (1921) Species and area. Journal of Ecology, 9, 95-99.

Atauri, J.A. \& de Lucio, J.V. (2001) The role of landscape structure in species richness distribution of birds, amphibians, reptiles and lepidopterans in Mediterranean landscapes. Landscape Ecology, 16, 147-159.

Bailey, D., Herzog, F., Augenstein, I., Aviron, S., Billeter, R. \& Baudry, J. (2007) Thematic resolution matters: indicators of landscape pattern for European agro-ecosystems. Ecological Indicators, 7, 692-709.

Benton, T.G., Vickery, J.A. \& Wilson, J.D. (2003) Farmland biodiversity: is habitat heterogeneity the key? Trends in Ecology and Evolution, 18, 182 188

Brooks, T. \& Kennedy, E. (2004) Conservation biology: biodiversity barometers. Nature, 431, 1046-1047.

Bruun, H.H. (2000) Patterns of species richness in dry grassland patches in an agricultural landscape. Ecography, 23, 641-650.

Davies, C.E. \& Moss, D. (1999) EUNIS Habitat Classification. Final Report to the European Topic Centre on Nature Conservation. European Environment Agency, Copenhagen.

Di Giulio, M. \& Edwards, P.J. (2003) The influence of host plant diversity and food quality on larval survival of plant feeding heteropteran bugs. Ecological Entomology, 28, 51-57.

Ditommaso, A. \& Aarssen, L.W. (1989) Resource manipulations in natural vegetation - a review. Vegetatio, 84, 9-29.

Donald, P.F., Pisano, G., Rayment, M.D. \& Pain, D.J. (2002) The Common Agricultural Policy, EU enlargement and the conservation of Europe's farmland birds. Agriculture, Ecosystems and Environment, 89, 167-182.

Duelli, P. (1997) Biodiversity evaluation in agricultural landscapes: an approach at two different scales. Agriculture Ecosystems and Environment, 62, 81-91.

Duelli, P. \& Obrist, M.K. (1998) In search of the best correlates for local organismal biodiversity in cultivated areas. Biodiversity and Conservation, 7, 297 309

Duelli, P. \& Obrist, M.K. (2003) Regional biodiversity in an agricultural landscape: the contribution of semi-natural habitat islands. Basic and Applied Ecology, 4, 129-138.

Edwards, P.J., Kollmann, J. \& Wood, D. (1999) The agroecosystem in the landscape: implications for biodiversity and ecosystem function. Agrobiodiversity: Characterization, Utilization and Management (eds D. Wood \& J.M. Lenné), pp. 183-210. CAB International, Wallingford, UK.

Fahrig, L. \& Jonsen, I. (1998) Effect of habitat patch characteristics on abundance and diversity of insects in an agricultural landscape. Ecosystems, 1 , 197-205.

Gough, L., Osenberg, C.W., Gross, K.L. \& Collins, S.L. (2000) Fertilization effects on species density and primary productivity in herbaceous plant communities. Oikos, 89, 428-439.

Grashof-Bokdam, C.J. \& van Langevelde, F. (2005) Green veining: landscape determinants of biodiversity in European agricultural landscapes. Landscape Ecology, 20, 417-439.

Green, R.E., Cornell, S.J., Scharlemann, J.P.W. \& Balmford, A. (2005) Farming and the fate of wild nature. Science, 307, 550-555. 
Hendrickx, F., Maelfait, J.P., van Wingerden, W. et al. (2007) How landscape structure, land-use intensity and habitat diversity affect components of total arthropod diversity in agricultural landscapes. Journal of Applied Ecology, 44, 340-351.

Herzog, F., Steiner, B., Bailey, D. et al. (2006) Assessing the intensity of temperate European agriculture at the landscape scale. European Journal of Agronomy, 24, 165-181.

van Jaarsveld, A.S., Freitag, S., Chown, S.L. et al. (1998) Biodiversity assessment and conservation strategies. Science, 279, 2106-2108.

Kati, V., Devillers, P., Dufrene, M., Legakis, A., Vokou, D. \& Lebrun, P. (2004) Testing the value of six taxonomic groups as biodiversity indicators at a local scale. Conservation Biology, 18, 667-675.

Kleijn, D. \& Snoeijing, G.I.J. (1997) Field boundary vegetation and the effects of agrochemical drift: botanical change caused by low levels of herbicide and fertilizer. Journal of Applied Ecology, 34, 1413-1425.

Kleijn, D. \& Sutherland, W.J. (2003) How effective are European agrienvironment schemes in conserving and promoting biodiversity? Journal of Applied Ecology, 40, 947-969.

Kleijn, D., Berendse, F., Smit, R. \& Gillisen, N. (2001) Agri-environmental schemes do not effectively protect biodiversity in Dutch agricultura landscapes. Nature, 413, 723-725.

Krebs, J.R., Wilson, J.D., Bradbury, R.B. \& Siriwardena, G.M. (1999) The second silent spring? Nature, 400, 611-612.

Kremen, C. (2005) Managing ecosystem services: what do we need to know about their ecology? Ecology Letters, 8, 468-479.

Kremen, C., Williams, N.M., Bugg, R.L., Fay, J.P. \& Thorp, R.W. (2004) The area requirements of an ecosystem service: crop pollination by native bee communities in California. Ecology Letters, 7, 1109-1119.

Lamoreux, J.F., Morrison, J.C., Ricketts, T.H. et al. (2006) Global tests of biodiversity concordance and the importance of endemism. Nature, 440, $212-214$.

Littell, R.C., Milliken, G.A., Stroup, W.W. \& Wolfinger, R.D. (1996) SAS System for Mixed Models. SAS Institute, Cary, NC, USA.

Loreau, M., Naeem, S., Inchausti, P. et al. (2001) Ecology - biodiversity and ecosystem functioning: current knowledge and future challenges. Science, 294, 804-808.

Magee, L. (1990) $R^{2}$ measures based on Wald and likelihood ratio joint significance tests. American Statistician, 44, 250-253.

Marshall, E.J.R. \& Moonen, A.C. (2002) Field margins in northern Europe: their functions and interactions with agriculture. Agriculture, Ecosystems and Environment, 89, 5-21.

Marshall, E.J.P., Brown, V.K., Boatman, N.D., Lutman, P.J.W., Squire, G.R. \& Ward, L.K. (2003) The role of weeds in supporting biological diversity within crop fields. Weed Research, 43, 77-89.

Mason, C.F. \& Macdonald, S.M. (2000) Influence of landscape and land-use on the distribution of breeding birds in farmland in eastern England. Journal of Zoology, 251, 339-348.

McGarigal, K., Cushman, S.A., Neel, M.C. \& Ene, E. (2002) Fragstats: Spatial pattern analysis program for categorical maps. www.umass.edu/landeco/ research/fragstats/fragstats.html

McGeoch, M.A. (1998) The selection, testing and application of terrestrial insects as bioindicators. Biological Reviews, 73, 181-201.

Myklestad, A. \& Saetersdal, M. (2005) Effects of fertilization and afforestation on community structure of traditionally managed hay meadows in western Norway. Nordic Journal of Botany, 23, 593-606.

Pearson, D.L. \& Cassola, F. (1992) Worldwide species richness patterns of tiger beetles (Coleoptera, Cicindelidae) - indicator taxon for biodiversity and conservation studies. Conservation Biology, 6, 376-391

Pharo, E.J., Beattie, A.J. \& Binns, D. (1999) Vascular plant diversity as a surrogate for bryophyte and lichen diversity. Conservation Biology, 13, 282-292.

Purtauf, T., Dauber, J. \& Wolters, V. (2005) The response of carabids to landscape simplification differs between trophic groups. Oecologia, 142, 458-464.

Robinson, R. \& Sutherland, W.J. (2002) Post-war changes in arable farming and biodiversity in Great Britain. Journal of Applied Ecology, 39, 157-176.

Sala, O.E., Chapin, F.S., Armesto, J.J. et al. (2000) Biodiversity - global biodiversity scenarios for the year 2100. Science, 287, 1770-1774.

Sauberer, N., Zulka, K.P., Abensperg-Traun, M. et al. (2004) Surrogate taxa for biodiversity in agricultural landscapes of eastern Austria. Biological Conservation, 117, 181-190.

Schweiger, O., Maelfait, J.P., Van Wingerden, W. et al. (2005) Quantifying the impact of environmental factors on arthropod communities in agricultura landscapes across organizational levels and spatial scales. Journal of Applied Ecology, 42, 1129-1139.
Shao, J. (1997) An asymptotic theory for linear model selection. Statistica Sinica, 7, 221-264.

de Snoo, G.R. \& van der Poll, R.J. (1999) Effect of herbicide drift on adjacent boundary vegetation. Agriculture, Ecosystems and Environment, 73, 1-6.

Steffan-Dewenter, I. (2003) Importance of habitat area and landscape context for species richness of bees and wasps in fragmented orchard meadows. Conservation Biology, 17, 1036-1044.

Steffan-Dewenter, I., Munzenberg, U., Burger, C., Thies, C. \& Tscharntke, T. (2002) Scale-dependent effects of landscape context on three pollinator guilds. Ecology, 83, 1421-1432.

Stoate, C. \& Parish, D. (2001) Crops grown on set-aside land bring wild birds back to the fields - monitoring is under way, and results so far are promising. Nature, 414, 687-687.

Stoate, C., Boatman, N.D., Borralho, R.J., Carvalho, C.R., Snoo, G.R. \& Eden, P. (2001) Ecological impacts of arable intensification in Europe. Journal of Environmental Management, 63, 337-365.

Tews, J., Brose, U., Grimm, V. et al. (2004) Animal species diversity driven by habitat heterogeneity/diversity: the importance of keystone structures. Journal of Biogeography, 31, 79-92.

Tilman, D., Fargione, J., Wolff, B. et al. (2001) Forecasting agriculturally driven global environmental change. Science, 292, 281-284.

Topping, C.J. \& Sunderland, K.D. (1992) Limitations to the use of pitfall traps in ecological-studies exemplified by a study of spiders in a field of winter wheat. Journal of Applied Ecology, 29, 485-491.

Tscharntke, T., Steffan-Dewenter, I., Kruess, A. \& Thies, C. (2002) Contribution of small habitat fragments to conservation of insect communities of grassland-cropland landscapes. Ecological Applications, 12, 354-363.

Tscharntke, T., Klein, A.M., Kruess, A., Steffan-Dewenter, I. \& Thies, C. (2005) Landscape perspectives on agricultural intensification and biodiversity ecosystem service management. Ecology Letters, 8, 857-874.

Vanbergen, A.J., Woodcock, B.A., Watt, A.D. \& Niemela, J. (2005) Effect of land-use heterogeneity on carabid communities at the landscape scale. Ecography, 28, 3-16.

Vessby, K., Soderstrom, B., Glimskar, A. \& Svensson, B. (2002) Speciesrichness correlations of six different taxa in Swedish semi-natural grasslands. Conservation Biology, 16, 430-439.

Watkinson, A.R., Freckleton, R.P., Robinson, R.A. \& Sutherland, W.J. (2000) Predictions of biodiversity response to genetically modified herbicidetolerant crops. Science, 289, 1554-1557.

Weibull, A.C., Bengtsson, J. \& Nohlgren, E. (2000) Diversity of butterflies in the agricultural landscape: the role of farming system and landscape heterogeneity. Ecography, 23, 743-750.

Westrich, P. (1996) Habitat requirements of Central European bees and the problems of partial habitats. The Conservation of Bees (eds A. Matheson, S.L. Buchmann, C. O’Toole, P. Westrich \& I. H. Williams), pp. 1-16. Academic Press, London.

Received 29 March 2007; accepted 19 July 2007

Handling Editor: Davy McCracken

\section{Supplementary material}

The following supplementary material is available for this article.

Table S1. Description of the landscape study sites.

This material is available as part of the online article from: http://www.blackwell-synergy.com/doi/full/10.1111/j.13652664.2007.01393.x.

(This link will take you to the article abstract.)

Please note: Blackwell Publishing is not responsible for the content or functionality of any supplementary material supplied by the authors. Any queries (other than missing material) should be directed to the corresponding author for the article. 